Bangladesh J. Plant Taxon. 16(1): 1-8, 2009 (June)

(C) 2009 Bangladesh Association of Plant Taxonomists

\title{
NEW RECORDS OF PHYTOPLANKTON FOR BANGLADESH.
} 9. SOME RARE AND A NEW SPECIES

\author{
Moniruzzaman Khondker ${ }^{1}$, Rauf Ahmed Bhuiyan, Jenat Yeasmin, Munirul Alam², \\ R. Bradley Sack ${ }^{3}$, Anwar Huq ${ }^{4}$ and Rita R. Colwell ${ }^{3,4,5}$ \\ Department of Botany, University of Dhaka, Dhaka 1000, Bangladesh.
}

Keywords: Rare species; Strombomonas islamii Khondker; Ponds; Bangladesh.

\begin{abstract}
Ten taxa belonging to Chlorophyceae, Cyanophyceae, Bacillariophyceae and Euglenophyceae, and one with an uncertain taxonomic position have been described in this paper. Of these, 10 taxa have been found to be globally rare and new records for Bangladesh, whereas Strombomonas islamii Khondker sp. nov. has been described as new to science.
\end{abstract}

\section{Introduction}

Islam $(1969,1972)$ studied some rare planktonic green algae in the Bangladesh territory. Recently, under the domain of a research project 'Epidemiology and Ecology of Vibrio cholerae in Bangladesh' an extensive collection programme of phytoplankton was performed in two southern coastal districts, namely Pirojpur and Barisal of Bangladesh between 2004 and 2007. In this programme, 13 domestic ponds and a river channel belonging to Mathbaria upazila of Pirojpur district and Bakerganj upazila of Barisal district were explored and the outcome was a collection of 1,008 samples.

While working on these plankton samples, the present authors noticed the occurrence of a number of interesting species which were rather difficult to identify. After an extensive literature search, some taxa were proved to be globally rare and one was designated as new to science. Other relatively common taxa worked out from the same collections, but proved to be new reports for Bangladesh, have been published in a series of papers (Khondker et al., 2006, 2007 a, b, c, d, 2008 a, b, c, d). The present paper records the systematic accounts of 10 rare taxa which are new records for Bangladesh and one new species of phytoplankton.

\section{Materials and Methods}

Net and Lugol's solution-sedimented samples of phytoplankton were used for the present study. Details of the methodology, frequency of sampling and description of the sampling stations could be found in Khondker et al. (2006).

\footnotetext{
${ }^{1}$ Corresponding author. E-mail: mkhondker@yahoo.com ${ }^{2}$ International Centre for Diarrhoeal Disease Research, Bangladesh, Dhaka, Bangladesh. ${ }^{3}$ Johns Hopkins Bloomberg School of Public Health, Baltimore, Maryland, USA. ${ }^{4}$ Centre of Marine Biotechnology, University of Maryland Biotechnology Institute, Baltimore, Maryland, USA. ${ }^{5}$ University of Maryland Institute for Advanced Computer Studies, College Park, Maryland, USA.
} 


\section{Taxonomic enumeration}

Systematic accounts of 10 rare taxa of phytoplankton have been provided with photomicrographs. One new species under the genus Strombomonas Delf. has also been described. Ten taxa belong to four algal classes, namely Chlorophyceae, Cyanophyceae, Bacillariophyceae and Euglenophyceae. Taxonomic position of one taxon is uncertain. In the description, the taxa are arranged after Smith (1950).

\section{Division: Chlorophyta; Class: Chlorophyceae; Order: Volvocales Family: Chlamydomonadaceae}

\section{Chlorogonium metamorphum Skuja}

(Fig. 8)

(Huber-Pestalozzi, 1961, 474, 97: 650a)

Cells elongated spindle-shaped, anterior end narrowed to a blunt end, posterior gradually narrowed to pointed end, $15 \mu \mathrm{m}$ long, $3 \mu \mathrm{m}$ broad. Cell membrane thin, smooth, colorless. Flagellum $15 \mu \mathrm{m}$ long, anteriorly placed.

Bakerganj, Station No. 8, 10.07.2006.

\section{Pandorina cylindricum Iyengar}

(Fig. 6)

(Iyengar and Desikachary, 1981,420, Text-Fig. 245:3; Ling and Tyler, 2000, 123, 55: 3)

Colony oblong to cylindrical, both ends slightly tapering to rounded. Mucilaginous sheath broad, much wider at both ends of the colony, 10-15 $\mu \mathrm{m}$ wide at ends. Cells pyriform, 16 in number, arranged in 4 tiers. Colony with mucilage sheath $70 \mu \mathrm{m}$ long, 40 $\mu \mathrm{m}$ broad, without mucilage sheath 50-55 $\mu \mathrm{m}$ long, 28-30 $\mu \mathrm{m}$ broad. Vegetative cells 14 $\mu \mathrm{m}$ long, $15 \mu \mathrm{m}$ wide at a maximum.

Bakerganj, Station No. 2, 17.04.2006.

\section{Division: Euglenophyta; Class: Euglenophyceae; Order: Colaciales Family: Colaciaceae}

3. Colacium ovale Playf

(Figs 13-16)

(Huber-Pestalozzi, 1955, 135)

Cells ovoid to elongated ovoid or spherical, attached, light green, 7.5-14.8 $\mu \mathrm{m}$ long, 4-7 $\mu \mathrm{m}$ broad.

Note: The species was reported from Australia and found to grow on the carapace of Copepods (HuberPestalozzi, 1955). In the present study the species grew attached to the lorica of Trachelomonas sp. HuberPestalozzi (1955), however, did not produce any figure of the species. The present taxon fits well with the measurements and description as provided by Huber-Pestalozzi (1955), and therefore, it has been tentatively placed under C. ovale. 

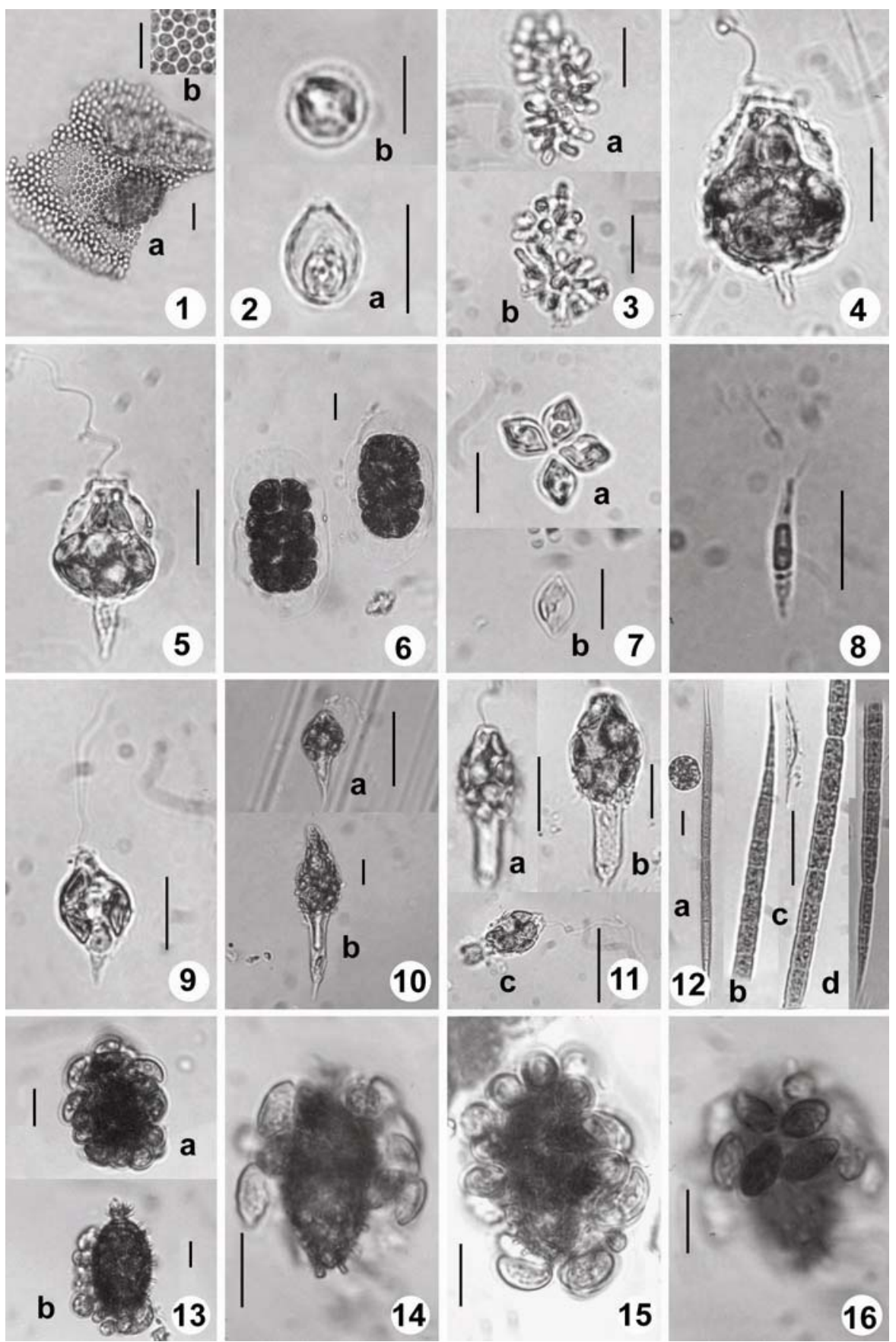

Figs 1-16. 1. Microcrocis granulata, a. thallus, b. enlarged view; 2. Paulinella chromatophora, a. organism, b. top view; 3. Aphanothece clathrata; 4, 5. Strombomonas acuminata var. deflandreana; 6. Pandorina cylindricum; 7. Achnanthes lacunarum; 8. Chlorogonium metamorphum; 9. Lepocinclis sphagnophila; 10 , 11. Strombomonas islamii sp. nov.; 12. Raphidiopsis mediterranea; 13-16. Colacium ovale. (Bars $=10$ $\mu \mathrm{m})$ 
Mathbaria, Station No. 6, 19.07.2004, 16.08.2004.

4. Lepocinclis sphagnophila Lemm.

(Fig. 9)

(Prescott, 1982, 406, 89: 11-13)

Cells ovoid to fusiform, posterior end gradually narrowed to a short pointed caudus, anterior suddenly narrowed to blunt apex, at the centre of which flagellum appears. Cells $19 \mu \mathrm{m}$ long, $11 \mu \mathrm{m}$ broad. Flagellum more than body length, $23 \mu \mathrm{m}$ long. Paramylon bodies 4 in number, plate-like, two on either side (in our material two on one side and one on the another side).

Bakerganj, Station No. 1, 07.12.2006.

5. Strombomonas acuminata var. deflandreana Conrad

(Figs 4, 5)

(Huber-Pestalozzi, 1955, 373, 77: 800).

Lorica nearly orbicular, irregularly warted, with a distinct, short but wide mouth part and an elongated, cuneate caudus. Lorica 26-30 $\mu \mathrm{m}$ long, $18 \mu \mathrm{m}$ broad. Mouth part 1.4 $\mu \mathrm{m}$ high, 6.1-6.7 $\mu \mathrm{m}$ broad. Caudus 6-11 $\mu \mathrm{m}$ long. Protoplasm massive, flask-shaped, in anterior region moved away from the lorica wall, 16-18 $\mu \mathrm{m}$ long, 15-17 $\mu \mathrm{m}$ broad. Flagellum very long, near about 3 times the body length.

Bakerganj, Station No. 1, 07.12.2006.

6. Strombomonas islamii Khondker sp. nov.

(Figs 10, 11)

Lorica fusiformis, leuteo-brunneus. Antico extrematus dumbbeliformis, postico cylindraceus cum apicalis appendix. Cellula contenta aggregatus in capitulum. Antico extrematus leviter angustata in extrematibus obtusatus, unde unus longus flagellum habitus. Lorica 27-74 $\mu \mathrm{m}$ longum, 13-20 $\mu \mathrm{m}$ latus ad capitulum. Caudus $14 \mu \mathrm{m}$ longum, orificium $3.3 \mu \mathrm{m}$ latus. Flagellum $60 \mu \mathrm{m}$ longum.

Lorica spindle-shaped, yellow brown. Anterior end dumbbell-head-like, posterior cylindrical with a terminal appendix. Cell content concentrated in the head region. Anterior end slightly narrowed to a blunt end, from which a long flagellum appears. Lorica 27-74 $\mu \mathrm{m}$ long, $13-20 \mu \mathrm{m}$ broad at the head region. Caudus $14 \mu \mathrm{m}$ long, mouth part $3.3 \mu \mathrm{m}$ broad. Flagellum $60 \mu \mathrm{m}$ long.

Holotype: Sample no. NHEB0610361, 27 November 2006, Bakerganj, Barisal district, collected by NIH Ecological Surveillance Team at ICDDR,B, Dhaka; Herbarium of Phycology, Hydrobiology and Limnology Laboratory, Department of Botany, University of Dhaka, Dhaka, Bangladesh.

Type locality: The sample was collected from a typical road side village pond named 'Bakerganj Helipad Government Pond' in Bakerganj, Barisal, Bangladesh, $Z_{\max }=2.4 \mathrm{~m}$, 
$A=371 \mathrm{~m}^{2}$. The water of the pond is used for bathing, washing and for other domestic uses by the villagers. The bank of the pond is covered with bushes and trees.

Ecology: Pelagic plankton. Some water quality data at the time of collection were: air temperature $28^{\circ} \mathrm{C}$, water temperature $24^{\circ} \mathrm{C}, \mathrm{pH} 8.2$, TDS $90 \mathrm{mg} / \mathrm{l}$, alkalinity $1.6 \mathrm{meq} / \mathrm{l}$, $\mathrm{PO}_{4}-\mathrm{P} 41.3 \mu \mathrm{g} / 1, \mathrm{NO}_{3}-\mathrm{N} 1.28 \mathrm{mg} / \mathrm{l}$, silicate $16.2 \mathrm{mg} / \mathrm{l}$ and chlorophyll a $574.5 \mu \mathrm{g} / \mathrm{l}$.

Distribution: So far known only from Bakerganj of Barisal district, Bangladesh.

Note: The present species has some likeliness with Strombomonas lackeyi (McCoy) Dillard (Dillard, 2000), but differs by the shape of head region, caudal region, lorica size and length of the flagellum. Strombomonas lackeyi has a flask-shaped anterior part, but the present material has a dumbbell-head-shaped anterior part. Caudal region in the former is conical, but cylindrical in the latter. The present specimen is nearly 1.7 times smaller than S. lackeyi. In S. lackeyi flagellum is about $121 \mu \mathrm{m}$ long, but in the present specimen it is $60 \mu \mathrm{m}$ long.

The species has been named in the honour of Prof. A.K.M. Nurul Islam, Department of Botany, University of Dhaka for his outstanding pioneering contribution to Phycology.

\section{Division: Chrysophyta; Class: Bacillariophyceae; Order: Pennales Family: Achnanthaceae}

7. Achnanthes lacunarum Hust.

(Fig. 7)

(Hustedt, 1930, 205, 297)

Frustules lanceolate, forming a star-shaped colony of 4 cells. Cells 9-13 $\mu \mathrm{m}$ long, 6-7 $\mu \mathrm{m}$ broad.

Bakerganj, Station No. 6, 01.11.2004.

\section{Division: Cyanophyta; Class: Cyanophyceae; Order: Chroococcales Family: Chroococcaceae}

8. Aphanothece clathrata W. et G.S. West

(Fig. 3)

(Geitler, 1925, 71, Text-Figs. 61; Prescott, 1982, 467, 104: 6-7)

Colony microscopic, free-floating, elliptical, 22-26 $\mu \mathrm{m}$ long, 13-14 $\mu \mathrm{m}$ broad. Cells cylindrical or rod-shaped, light to deep blue-green in colour, densely packed, straight or lightly curved, 3-5 $\mu \mathrm{m}$ long, 1.0-1.3 $\mu \mathrm{m}$ broad. Mucilage transparent.

Note: The species forms large, often irregular, clathrate colonies with homogeneous mucilage when grown in benthic condition. Under planktonic condition it does not develop clathrate colonies rather microscopic and small colonies (Desikachary, 1959). The present material was collected from a bloom in a pond.

Bakerganj, Station No. 1, 27.11.2006. 
9. Microcrocis granulata Skuja

(Fig. 1)

(Starmach, 1966, 68, Text-Fig. 55).

Colonial, sheet-like. Sheets convoluted at both ends, c $90 \mu \mathrm{m}$ long, $66 \mu \mathrm{m}$ broad. Cells look polygonal or hexagonal, $2.5 \mu \mathrm{m}$ broad. Cell content prominent blue-green.

Mathbaria, Station No. 3, 03.10.2004.

\section{Family: Rivulariaceae}

\section{Raphidiopsis mediterranea Skuja}

(Fig. 12)

(Desikachary, 1959, 432, 79: 2-3)

Trichome free-living, straight, both ends attenuated, composed of 12 cells. After fragmentation trichome rounded at one end. Trichome $132 \mu \mathrm{m}$ long, $5 \mu \mathrm{m}$ broad. Cells in the middle of trichome 6.2-7.6 $\mu \mathrm{m}$ long, $4.2-5.0 \mu \mathrm{m}$ broad, end cells $17.8 \mu \mathrm{m}$ long. One end of trichome blunt, measures 40.6-81.2 $\mu \mathrm{m}$ long, $2.5 \mu \mathrm{m}$ broad, terminal cell $5.0 \mu \mathrm{m}$ long, $2.5 \mu \mathrm{m}$ broad.

Bakerganj, Station No. 8, 10.07.2006.

\section{Incertae Sedis}

11. Paulinella chromatophora Lauterborn

(Fig. 2)

(Desikachary, 1959, 54, Text-Fig. 1; Edmondson, 1959, 253, Text-Fig. 9.83; Ling and Tyler, 2000, 60, 19: 4-7)

Shell pear-shaped, colorless. Anterior with an oval aperture provided with a short neck, posterior broadly rounded. Protoplasm contains 1-2 sausage-shaped curved cyanellae. Shell $11 \mu \mathrm{m}$ long, $8 \mu \mathrm{m}$ broad at the base. Cyanellae c $6 \mu \mathrm{m}$ long (at curved state), 1.5-2.0 $\mu \mathrm{m}$ broad, light blue-green in colour.

Note: The specimen is a thecate amoeba inhabiting one or two cyanellae. It was collected with samples of phytoplankton. Similar observation was also made by Ling and Tyler (2000).

Bakerganj, Station No. 8, 09.08.2004.

\section{Acknowledgements}

The research as an integral part of the major multidisciplinary project entitled 'Epidemiology and Ecology of Vibrio cholerae in Bangladesh' was financed by the National Institute of Health (NIH) research grant \# 1RO1A13912901 under the collaborative agreement between the International Centre for Diarrhoeal Disease Research, Bangladesh (ICDDR,B) and Johns Hopkins Bloomberg School of Public Health. The authors gratefully acknowledge the NIH Ecological Surveillance Team at 
ICDDR,B for kindly supporting this research. Latin diagnosis of the new species done by Prof. Syed Hadiuzzaman, Department of Botany, University of Dhaka is also gratefully acknowledged.

\section{References}

Desikachary, T.V. 1959. Cyanophyta. ICAR, New Delhi, India, pp. 1-686.

Dillard, G.E. 2000. Freshwater algae of the Southeastern United States. Part 7. Pigmented Euglenophyceae. J. Cramer, Stuttgart, pp. 1-136+ pls 20.

Edmondson, W.T. (ed.) 1959. Freshwater Biology. John Wiley \& Sons Inc., pp. 1-1248.

Geitler, L. 1925. Die Süßwasserflora. Deutschlands, Österreichs und der Schweiz. Heft 12: Cyanophyceae. Jena Verlag von Gustav Fischer, pp. 1- 462.

Huber-Pestalozzi, G. 1955. Das Phytoplankton des Süsswassers. Systematik und Biologie. 4. Teil: Euglenophyceen. E. Schweizerbart'sche Verlagsbuchhandlung (Nägele u. Obermiller), Stuttgart, Germany, pp. 1-606 + pls 1-114.

Huber-Pestalozzi, G. 1961. Das Phytoplankton des Süsswassers. Systematik und Biologie. 5. Teil: Chlorophyceae (Grünalgen), Ordnung: Volvocales. E. Schweizerbart'sche Verlagsbuchhandlung (Nägele u. Obermiller), Stuttgart, Germany, pp. 1-744 + pls 1-157.

Hustedt, F. 1930. In Pascher's Die Süsswasserflora. Heft: 10, Bacillariophyta (Diatomeae). Verlag von Gustav Fischer, Jena, pp. 1-466.

Islam, A.K.M. Nurul 1969. Some rare planktonic green algae found in East Pakistan. Pakistan J. Botany 1 : 19-32.

Islam, A.K.M. Nurul 1972. New and rare species of some green algae from Bangladesh. Nova Hedwigia 23: $655-663+$ pls 1-14.

Iyengar, M.O.P. and Desikachary, T.V. 1981. Volvocales. Indian Council of Agricultural Research, New Delhi, pp. 1-531.

Khondker, M., Bhuiyan, R.A., Yeasmin, J., Alam, M., Sack, R.B., Huq, A. and Colwell, R.R. 2006. New records of phytoplankton for Bangladesh. 1. Cyanophyceae. Bangladesh J. Bot. 35(2): 173-179.

Khondker, M., Bhuiyan, R.A., Yeasmin, J., Alam, M., Sack, R.B., Huq, A. and Colwell, R.R. 2007a. New records of phytoplankton for Bangladesh. 2. Cryptophyceae, Xanthophyceae and Synurophyceae. Bangladesh J. Bot. 36(1): 53-59.

Khondker, M., Bhuiyan, R.A., Yeasmin, J., Alam, M., Sack, R.B., Huq, A. and Colwell, R.R. 2007b. New records of phytoplankton for Bangladesh. 3. Order: Volvocales. Bangladesh J. Plant Taxon. 14(1): 1-12.

Khondker, M., Bhuiyan, R.A., Yeasmin, J., Alam, M., Sack, R.B., Huq, A. and Colwell, R.R. 2007c. New records of phytoplankton for Bangladesh. 4. Order: Chlorococcales. Bangladesh J. Plant Taxon. 14(2): 83-91.

Khondker, M., Bhuiyan, R.A. and Yeasmin, J. 2007d. Colacium vesiculosum Ehr.: A new record for Bangladesh. Bangladesh J. Bot. 36(2): 195-197.

Khondker, M., Bhuiyan, R.A., Yeasmin, J., Alam, M., Sack, R.B., Huq, A. and Colwell, R.R. 2008a. New records of phytoplankton for Bangladesh. 5. Euglena, Euglenocapsa. Bangladesh J. Plant Taxon. 15(1): $39-46$. 
Khondker, M., Bhuiyan, R.A., Yeasmin, J., Alam, M., Sack, R.B., Huq, A. and Colwell, R.R. 2008b. New records of phytoplankton for Bangladesh. 6. Lepocinclis Perty, Strombomonas Defl., Astasia Dujardin, Menoidium Perty. Bangladesh J. Plant Taxon. 15(2): 107-114.

Khondker, M., Bhuiyan, R.A., Yeasmin, J., Alam, M., Sack, R.B., Huq, A. and Colwell, R.R. 2008c. New records of phytoplankton for Bangladesh. 7. Phacus. Bangladesh J. Botany 37(1): 55-60.

Khondker, M., Bhuiyan, R.A., Yeasmin, J., Alam, M., Sack, R.B., Huq, A. and Colwell, R.R. 2008d. New records of phytoplankton for Bangladesh. 8. Trachelomonas Ehr. Bangladesh J. Botany 37(2): 133-139.

Ling, H.U. and Tyler, P.A. 2000. Australian Freshwater Algae (exclusive of diatoms). Bibl. Phycol. Bd. 105. J. Cramer, Gebrüder Brontraeger Verlagsbuchhandlung, Berlin, pp. 1-643.

Prescott, G.W. 1982 (Reprinted). Algae of the Western Great Lakes Area. Otto Koeltz Sci. Publ., W. Germany, pp. 1-977.

Smith, G.M. 1950. The freshwater algae of the United States. McGraw-Hill Book Co. New York, pp. 1-719.

Starmach, K. 1966. Cyanophyta-sinice, Glaucophyta-Glaukofity. Flora Słodkowodna Polski. Tom-2. Polska Akademia Nauk, Warszawa, pp. 1-806.

(Manuscript received on 22 January 2008; revised on 22 November 2008) 